\title{
Persistence of malathion used in dengue control on household surfaces
}

\section{Permanência do malathion usado no controle da dengue em superfícies domiciliares}

\author{
Regina Cristina Batista Ferreira' (D), Solange Papini² (D), Luiz Carlos Luchini' ${ }^{1}$, Eliane Vieira ${ }^{*}$ (D) \\ | | | | | | | | | | | | | | | | | | | | | | | | | | | | | | | | | | | | | | | | | | | | | | | | | | | | | | | | | | | | | | | | | | | | | | | | | | | | | | | | | | | | | | | | | | | | | | | | | | | | | | | | | | | | | | | | | | | | | | | | | | | | | | | | | | | | | | | | | | | | | | | | | | | | | | | | | | | | | | | | | | | | | | | | | | | | | | | | | | | | | | | | | | | | | | | | | | | | |
}

\begin{abstract}
Dengue is a viral infection transmitted by the mosquito Aedes aegypti. In Brazil, one of the insecticides used to control the mosquito is malathion, which can be diluted in vegetable oil $(1: 2 \mathrm{v} / \mathrm{v})$. The purpose of this study was to understand the persistence of malathion on different surfaces and soil. Surfaces were contaminated by malathion and then washed with water and soap. The water used to clean the surfaces was extracted and analyzed by gas chromatography with an FID detector. Soil samples received malathion ${ }^{14} \mathrm{C}-\mathrm{TG}$ diluted in vegetable oil $(1: 2 \mathrm{v} / \mathrm{v})$ and were analyzed zero, 3, 7, $18,32,60,120,240$, and 360 days after the application in a liquid scintillation analyzer. Results showed a high persistence of malathion on porous surfaces. Moreover, it did not degrade in the soil for the first 120 days.
\end{abstract}

KEYWORDS: Aedes aegypti; urban area; indoor application; pesticides.
RESUMO: A dengue é uma infecção viral transmitida pelo mosquito Aedes aegypti. No Brasil, um dos inseticidas utilizados para controlar o mosquito é o malathion, que pode ser diluído em óleo vegetal $(1: 2 \mathrm{v} / \mathrm{v})$. O objetivo deste trabalho foi avaliar a permanência do malathion em diferentes superfícies e no solo. As superfícies foram contaminadas com malathion e depois lavadas com água e sabão. A água utilizada para limpar as superfícies foi extraída e analisada por cromatografia gasosa com detector de ionização de chama. O malathion ${ }^{14} \mathrm{C}-\mathrm{GT}$ diluído em óleo vegetal $(1: 2 \mathrm{v} / \mathrm{v})$ foi aplicado em amostras de solo que foram analisadas nos tempos $0,3,7,18$, 32, 60, 120, 240 e 360 dias após a aplicação, em um analisador de cintilação líquida. Os resultados mostraram alta permanência de malathion em superfícies porosas. Além disso, o malathion não se degradou no solo nos primeiros 120 dias.

PALAVRAS-CHAVE: Aedes aegypti; área urbana; aplicação indoor; pesticidas. 


\section{INTRODUCTION}

Urban spaces are important environments for studies related to pesticide behavior. Many studies are being carried out in this area (BOUVIER et al., 2006; ASTIZ et al., 2011; CETTIER et al., 2015), especially in the United States and Europe. However, they continue to be scarce in Brazil and Latin America, requiring the joint efforts of different researchers to understand the fate of these products in urban areas.

Dengue is a global issue (CENTERS FOR DISEASE CONTROLAND PREVENTION, 2015a) and one of the most important arthropod-borne viral diseases (WORLD HEALTH ORGANIZATION, 2009). This disease is also expensive as it often results in hospitalization (TOMASELLO; SCHLAGENHAUF, 2013); more than one-third of the population is at risk of contracting the disease (CENTERS FOR DISEASE CONTROL AND PREVENTION, 2015a). Central America, Asia, and South America are the most affected regions according to the dengue map of the world; however, there have been reported cases in some countries in Europe and Africa (CENTERS FOR DISEASE CONTROL AND PREVENTION, 2015b).

Aedes aegypti is fully adapted to urban conditions, where it finds shelter and food (WORLD HEALTH ORGANIZATION, 2009). Young forms are mainly found outdoors, while adult females prefer the interior of buildings (HERMANN et al., 2015). The lack of a vaccine to immunize the exposed population, coupled with the great adaptability of $A$. aegypti in urban environments, makes it difficult to control this endemic disease (HERMANN et al., 2015). The Dengue Control Program is primarily based on instructing the population on how to avoid the proliferation of mosquitoes, managing the environment, and in certain situations, applying insecticides (WORLD HEALTH ORGANIZATION, 2009). However, the use of these chemicals can impact the environment and public health, especially because of the high concentration of pesticides used in these campaigns.

Some locations of the São Paulo urban area have experienced a higher incidence of dengue (ARAUJO et al., 2015). In Brazil, until 2015, numerous cities used a technical-grade malathion organophosphate insecticide $96 \%$ diluted in vegetable oil 1:2 v/v (LEME et al., 2014), a procedure recommended by the WORLD HEALTH ORGANIZATION (2009). This mixture is used to produce a liquid spray to control adult mosquitoes. The insecticide malathion is indicated for use in agriculture and public health campaigns, being classified as toxicity class III (LEWIS et al., 2016). This insecticide is applied using a misting device for ultra-low volume applications, spraying droplets with a diameter of about 5 and $25 \mu \mathrm{m}$ (LEME et al., 2014). These droplets remain suspended for some time, eventually settling on different surfaces in a residence. Drops might also fall on the soil of gardens and backyards, unpaved streets, and inside houses that have mud floors. The latter two situations usually happen in low-income areas in Brazil, which are more susceptible to different diseases, including dengue (COSTA; NATAL, 1998).

The INTERNATIONAL AGENCY FOR RESEARCH ON CANCER (IARC, 2015) reclassified malathion as "probably carcinogenic to humans". In a study conducted by GENG et al. (2015), male rats showed changes in the reproductive system. CRUZ MÁRQUEZ et al. (2001) found $\alpha$ - and $\beta$-malathion monocarboxylic acid - a metabolite of malathion - in the applicators twenty hours after application. ASTIZ et al. (2011), who worked in this activity for about ten years, found significant differences in biochemical tests in their study on pesticide applicators.

Neither the persistence of malathion applied to surfaces in a house nor the potential risks to health and the environment are known yet. This study assessed the persistence of malathion diluted in vegetable oil deposited on different household surfaces and urban soil.

\section{MATERIAL AND METHODS}

\section{Chemical analysis}

Analytical standard malathion, with a chemical purity higher than 99\%, provided by Chemservice (West Chester, Pennsylvania, United States), was used to establish the analytical conditions, while $96 \%$ technical-grade malathion, provided by São Paulo City Hall, and ${ }^{14} \mathrm{C}$-specific activity 170.2 Bq malathion, provided by Izotop (Budapest, Hungary), were used in laboratory tests. We analyzed the $96 \%$ technical-grade malathion to confirm the concentration of the active ingredient present. The active ingredient (malathion) was detected and quantified by gas chromatography with a Shimadzu (Shimadzu Corp., Tokyo, Japan) external standard equipment, model GC-2014AFsc, equipped with a flame ionization detector, set at $300^{\circ} \mathrm{C}$. We conducted the analyses using a separation column Restek ${ }^{\mathrm{TM}}$ RTX-5 with $30 \mathrm{~m}$ length, $0.25 \mathrm{~mm}$ internal diameter, and $0.25 \mu \mathrm{m}$ film thickness. The column temperature was set at: $60^{\circ} \mathrm{C}$ for 0 minute; $25^{\circ} \mathrm{C} \cdot \mathrm{min}^{-1}$ to $250^{\circ} \mathrm{C}$ for 3 minutes; and $30^{\circ} \mathrm{C} \cdot \mathrm{min}^{-1}$ for 5 minutes. The last step was to clean the column. Nitrogen was the carrier gas at $1.0 \mathrm{~mL} \cdot \mathrm{min}^{-1}$. Hydrogen flow was kept at $3.0 \mathrm{~mL} \cdot \mathrm{min}^{-1}$ and synthetic air at $100.0 \mathrm{~mL} \cdot \mathrm{min}^{-1}$. The injection volume was $1 \mu \mathrm{L}$, and the injector temperature was $250^{\circ} \mathrm{C}$ in a split mode (1:1). The ${ }^{14} \mathrm{C}$-malathion used for soil analysis was assessed using a Packard Liquid Scintillation Analyzer, Packard TRICARB 1600TR (Waltham, Massachusetts, United States).

\section{Surfaces}

We sprayed different surfaces $(15 \times 15 \mathrm{~cm}$ plates $)$ with malathion $-0.5 \mathrm{~mL}$ of malathion in soybean oil $(1: 2 \mathrm{v} / \mathrm{v})$. 
The initial concentration applied was $711 \mu \mathrm{g} \mathrm{cm}^{-2}$. Surfaces were washed with soap and water, using toilet paper fragments weighing $18.3 \pm 0.2 \mathrm{~g} \mathrm{~m}^{2}(20 \times 10 \mathrm{~cm})$ or pieces of sponge $(3 \times 3 \mathrm{~cm})$ for cleaning. The sponges used were the fruits of Luffa cylindrica, a vegetable fiber abundant in the tropics (TANOBE et al., 2005).

We cleaned slate and tile plates using paper and sponge. Wood, leather, synthetic leather ( $70 \%$ vinyl-poly, $25 \%$ polyester, and 5\% polyurethane), and vinyl flooring were cleaned only with sponges. Surfaces were washed with $100 \mathrm{~mL}$ of water and $1.6 \mathrm{~g}$ of soap, scrubbed with a sponge and washed again with $100 \mathrm{~mL}$ of water. Both portions of water were placed together and extracted by the liquid-liquid method (ENVIRONMENTAL PROTECTION AGENCY, 2012). We washed the pieces of cotton cloth samples with $200 \mathrm{~mL}$ of water and $3.2 \mathrm{~g}$ of soap. Two washing methods were used: manual washing by scrubbing the samples and mechanical agitation for one hour.

\section{Soil}

The soil used was collected from an urban area southeast of Sáo Paulo city $\left(23^{\circ} 38^{\prime} 25.9 \mathrm{~S}\right.$ and $\left.46^{\circ} 39^{\prime} 08.5 \mathrm{~W}\right)$. The soil was dried at room temperature, sieved through a $2 \mathrm{~mm}$ mesh, and analyzed for physical-chemical characteristics in the Department of Soil Science, School of Agriculture "Luiz de Queiroz" (University of São Paulo), with the following results: $\mathrm{pH}\left(\mathrm{H}_{2} \mathrm{O}\right)-7.3$; organic matter $-24 \mathrm{~g}^{\mathrm{kg}}{ }^{-1}$; sand $-469 \mathrm{~g} \cdot \mathrm{kg}^{-1}$; silt $-120 \mathrm{~g} \cdot \mathrm{kg}^{-1}$; clay $-411.1 \mathrm{~g} \cdot \mathrm{kg}^{-1}$.

\section{ANALYTICAL METHODOLOGY}

\section{Sponge}

The sponge used for cleaning was submitted to extraction with $50 \mathrm{~mL}$ of dichloromethane in a shaker for 30 minutes. The dichloromethane was used for water extraction.

\section{Wash water}

Water $(200 \mathrm{~mL})$ was extracted with $10 \mathrm{~mL}$ of dichloromethane (3 times) and $20 \mathrm{~g}$ of $\mathrm{NaCl}$ in a separatory funnel, and the organic layer was collected using $\mathrm{Na}_{2} \mathrm{SO}_{4}$ (ENVIRONMENTAL PROTECTION AGENCY, 2012). We used a vacuum rotary evaporator at temperatures below $40^{\circ} \mathrm{C}$ for concentration until reaching a $10 \mathrm{~mL}$ volume.

\section{Toilet paper}

As the paper used for cleaning dissolved in water, it was extracted in a separatory funnel with the cleaning water.

\section{Cotton cloth}

Malathion was applied to pieces of cotton cloth $(15 \times 15 \mathrm{~cm})$, which were later washed with soapy water and scrubbed by hand or shaken in a mechanical shaker. The water obtained from the washing underwent an extraction procedure, while the cloth fragments that were "clean" and dry were subjected to extraction with $150 \mathrm{~mL}$ of dichloromethane using mechanical stirring for $30 \mathrm{~min}$. Dichloromethane was concentrated until reaching a $10 \mathrm{~mL}$ volume.

\section{Soil}

After drying, the soil was sieved through a $2 \mathrm{~mm}$ sieve. Next, we placed 27 samples with $10 \mathrm{~g}$ of soil in Falcon tubes prepared and spiked with $500 \mu \mathrm{L}$ of a solution of malathion and ${ }^{14} \mathrm{C}$--malathion, after which the samples presented $0.016 \mathrm{~g}$ of malathion and $8.12 \mathrm{~Bq}$ per gram of soil. Samples were kept at room temperature, ranging from a maximum temperature of $33.3^{\circ} \mathrm{C}$ and minimum of $15.2^{\circ} \mathrm{C}$, and a maximum humidity of $85 \%$ and minimum of $45 \%$. We analyzed the samples, in triplicate, at Tzero (time 0 ), T3, T7, T18, T32, T60, T120, T240, and T360 days. At each time, 3 samples were randomly taken and subjected to extraction procedures, adding $2.5 \mathrm{~mL}$ of distilled water, $4 \mathrm{~g}$ of sodium chloride, $2 \mathrm{~g}$ of sodium acetate, $8 \mathrm{~g}$ of magnesium sulfate, and $20 \mathrm{~mL}$ of $1 \%$ acetic acid in acetonitrile. The Falcon tubes were shaken vigorously for 1 minute by hand. Afterward, the samples were centrifuged at 3,000 rpm for 15 minutes. Subsequently, $500 \mu \mathrm{L}$ aliquots of each sample were added to the scintillation fluid and analyzed to detect ${ }^{14} \mathrm{C}$-malathion.

\section{Statistical analysis}

Due to the use of radioactive material (health and environmental risks) in the experiments, the number of samples analyzed was small. We considered a relevant difference of $20 \%$ sufficient to conclude that malathion was degraded and/or removed in comparison to the initial amount applied. We adopted a power test of $80 \%$, with a $10 \%$ difference between the averages and a $5 \%$ significance level. The Kolmogorov-Smirnov test assessed the normality of the data, the $\mathrm{F}$ test verified whether the variances were equal or not, and the Student's $t$ test checked if there was a significant difference among data. All tests were carried out using Action Excel.

\section{RESULTS}

The results obtained from the extraction of samples and the analyses of extracts by gas chromatography are presented as mean and standard deviation. We compared these results with the initial concentration applied $\left(711 \mu \mathrm{g} \mathrm{cm}^{-2}\right)$ and used them to calculate the percentage of malathion persistence (Table 1). 
Table 2 presents the results of the recovery of extracted washed and dried cloths. The data show that malathion was present even after the cloths were washed with water and soap using both methodologies (by hand and mechanically).

We analyzed all soil samples in triplicate for each exposure time and obtained the results by liquid scintillation spectrometry. The results for each exposure time were compared with the initial concentration applied (Tzero) and used to calculate the percentage of malathion present in the soil (Fig. 1). The concentration did not change until T120. At T240, we found a slight variation.

Table 1. Percentage of malathion removed from surfaces.

\begin{tabular}{|lcc|}
\hline Surface & $\begin{array}{c}\text { Concentration } \\
\left(\mu \mathrm{cm}^{-2}\right)\end{array}$ & $\begin{array}{c}\% \text { of malathion } \\
\text { in water } \pm \text { SD }\end{array}$ \\
\hline Paper cleaning $(\mathrm{n}=3)$ & & \\
\hline Tile & 484.4 & $67.9 \pm 6.0$ \\
\hline Slate & 537.8 & $75.8 \pm 5.3$ \\
\hline L. cylindrica cleaning $(\mathrm{n}=5)$ & & \\
\hline Tile & 657.8 & $92.5 \pm 5.8$ \\
\hline Slate & 653.3 & $91.7 \pm 5.5$ \\
\hline Vinyl flooring & 440.0 & $61.9 \pm 15.7$ \\
\hline Wood & 97.8 & $13.7 \pm 2.1$ \\
\hline Leather & 355.5 & $50.0 \pm 5.7$ \\
\hline Synthetic leather & 7.1 & $1.0 \pm 0.56$ \\
\hline
\end{tabular}

SD: standard deviation.

Table 2. Percentage of malathion removed from soapy water and washed cotton cloths [hand wash (A) and mechanical agitation (B)].

\begin{tabular}{|ccc|} 
Surface & $\begin{array}{c}\text { Concentration } \\
\left(\mathrm{mg} \cdot \mathrm{mL}^{-1}\right)\end{array}$ & $\begin{array}{c}\% \text { of malathion } \\
\text { in water } \pm \text { SD }\end{array}$ \\
\hline Soapy water used to wash cotton cloths $(\mathrm{n}=3)$
\end{tabular}

SD: standard deviation.

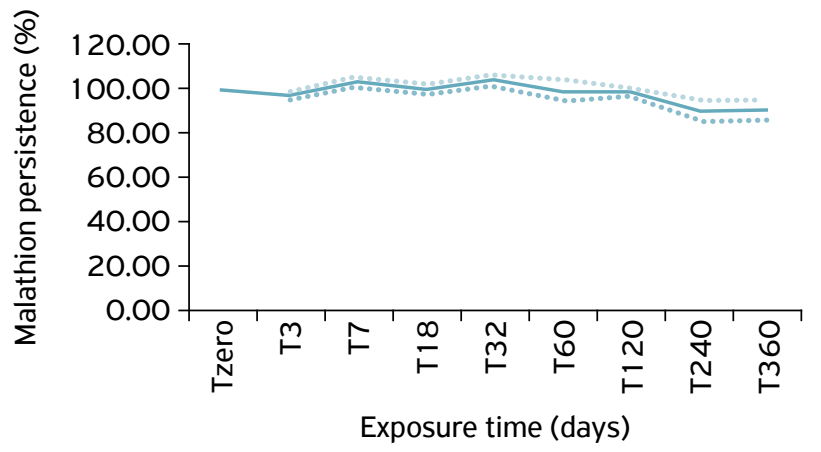

Figure 1. Persistence of ${ }^{14} \mathrm{C}$-malathion in soil.
The active ingredient (malathion) did not degrade in the soil during the first 120 days of testing. Its recovery was above $96 \%$ compared to the first day of application, showing great stability in the soil used and in exposure conditions. The concentration of ${ }^{14} \mathrm{C}$-malathion presented no significant difference between T3 and Tzero $(p=0.26)$, T7 and Tzero $(p=0.76)$, T18 and Tzero $(\mathrm{p}=0.12), \mathrm{T} 32$ and Tzero $(\mathrm{p}=0.08), \mathrm{T} 60$ and Tzero $(\mathrm{p}=0.38)$, and T120 and Tzero $(\mathrm{p}=0.14)$. However, we found a significant difference between T240 and Tzero $(\mathrm{p}=0.01)$. T360 showed a decrease in significance compared to Tzero, which confirms the degradation observed in T240.

\section{DISCUSSION}

Levels of malathion remained high on indoor surfaces even after cleaning. Removal of the active ingredient can differ significantly, depending on the type of surface, mainly due to its degree of porosity (Table 1 ).

The results of using toilet paper to remove malathion from tile and slate revealed that about 32 and $24 \%$ of the active ingredient, respectively, remained. When we cleaned the same surfaces with a sponge, malathion removal was above 96 and $91 \%$, showing that abrasive materials are more effective in eliminating the product from these surfaces.

Malathion persistence in vinyl flooring was approximately $62 \%$, even after using a sponge to clean it. The analysis was repeated due to the high variation coefficient in vinyl material (15.7). However, the new removal values were 36.9, 68.8, and $67.6 \%$ with a coefficient of variation of 31.3 . The same technician carried out all experiments using the same procedure over a short period, which indicates that the manual cleaning process can lead to non-homogeneous results on surfaces with high porosity.

Wood was another surface difficult to clean since $85 \%$ of malathion remained on the material. Many pieces of household furniture, such as dressers, closets, nightstands, chairs, tables, and kitchen cabinets, among others, are made of wood. People keep clothes, cutlery, dishes in them, which can expose these objects to contact with the insecticide. Collecting pesticides from hardwood is difficult due to its porosity (ASTIZ et al., 2011). The period for which malathion diluted in oil stays stable on this surface is not known, as there are no studies about this.

On leather, the persistence was about $53 \%$, while on synthetic leather, it was $99 \%$. This result shows that malathion was practically not removed from synthetic leather, even when cleaned with a sponge. These values were disturbing since this material is often used in the manufacture of furniture upholstery, leading to exposure as people spend part of their day in contact with them. Moreover, nowadays, synthetic leather is more used than leather because of the costs and environmental repercussions.

The fact that the active ingredient was not removed during a common domestic cleaning procedure can raise some 
questions. Malathion remained on all porous surfaces studied after cleaning. Pesticides sprayed on surfaces may be absorbed by the materials, and the cleaning procedure may be ineffective in removing all contaminants (ZOUBIRI, 2011). BOUVIER et al. (2006) found that malathion was frequently found on the hands of the general population, who were sometimes exposed to pesticides at levels higher than occupational exposure levels. Part of the product remained on the surface, which might lead to contact with people. On the other hand, if these surfaces absorb part of the applied product, there is no information if a deeper domestic cleaning with substances that have organic solvents, such as alcohol, hydrocarbon mixture, and furniture polishes, can extract some part of the active ingredient. Thus, further studies to evaluate whether the product remains on the surface or is absorbed are necessary. In case the active ingredient is deeply absorbed by the surfaces, contact with or exposure to malathion might not occur, which would be good. In addition, evaluating if malathion can be transferred from exposed surfaces to other surfaces, including the human skin, is also necessary.

Analyses of the water used to wash cotton cloths exposed to the insecticide provided interesting results. Two procedures were used for washing; by hand and using mechanical agitation, simulating a washing machine. In both cases, the water obtained from the washing was subjected to extraction, after which the extracts were analyzed by gas chromatography. Also, in both cases, the washed and dried cloths were subjected to extraction to determine the presence of pesticide residues. In the cloths washed by hand, malathion persistence was about $51 \%$, whereas in the cloths washed using mechanical stirring, the persistence was approximately $86 \%$, with a significant difference between the two procedures $(p=0.0000)$. Hand washing was possibly more effective due to the greater pressure involved during the scrubbing of the material, as opposed to mechanical agitation, in which only soapy water comes into contact with the material, with no pressure from scrubbing. As expected, the extraction of cloths already washed and dried showed that removal reached $38.2 \%$ in cloths washed by hand and $51.9 \%$ in those washed by mechanical agitation, indicating a significant difference between them $(\mathrm{p}=$ 0.0001). Results of cotton cloths washed mechanically were more homogeneous than of those washed manually, as the possibility of repeatability is higher in a mechanical process.

Analyses of water from the washed cotton cloths showed that the procedures adopted were not able to remove $100 \%$ of the insecticide. Therefore, we can conclude that personal garments, towels, baby cots and strollers, curtains, carpets, among others, retain part of the insecticide on their surfaces. Furthermore, it is noteworthy that baby cots, strollers, and carpets, for example, are usually not washed with soap and water, which means that once they come into contact with the insecticide, it will remain on their surface. In a study on clothes used as personal protective equipment in the spraying of malathion in urban areas, the authors found the cotton clothes were not completely cleaned in the washing process, with some malathion remaining in them (PAPINI et al., 2016). A study by the US military on clothing made with $100 \%$ cotton and exposed to permethrin showed that after one and ten washes, only 20 and $40 \%$ of the pesticide was removed, respectively (SNOGRASS, 1992), indicating that the rest remained in the clothes and, therefore, could contribute to the exposure of workers using this equipment. DAVIES et al. (1982) also noted the danger of incomplete washing of personal protective equipment. They observed washings at home to remove dichlorodiphenyltrichloroethane (DDT), methyl parathion, and toxaphene and determined that three washes were not sufficient to eliminate the residue.

Presently, in urban spaces, Brazil uses malathion $44 \%$ diluted in water to control $A$. aegypti, the change of oil for water occurred in 2016. Malathion has low environmental persistence when applied to an aqueous vehicle (LEWIS et al., 2016). However, the World Health Organization recommends using both oil and water in outdoor applications, as oil inhibits evaporation of small fog droplets (WORLD HEALTH ORGANIZATION, 2009), which is an important issue in tropical countries such as Brazil.

When using a malathion formulation prepared with oil, it is crucial to evaluate the methodology used to spray the oily solution with jets directed to residences to minimize the potential risk for people, especially children and older adults, who are the most vulnerable groups.

We also underline that, in general, dengue cases occur in several sites near peripheral regions of large cities in developing countries, where housing conditions are often inadequate. In this situation, spraying is mandatory, which theoretically can increase the concentration of insecticide on different surfaces, thus raising the possibility of exposure for people.

Pyrethroid is another group broadly used in urban areas that has been widely detected, including in indoors spaces (TANG et al., 2018). Cypermethrin and beta-cyfluthrin are pyrethroids used in indoor application, and supermarkets in Brazil sell formulations of these compounds; besides, some pyrethroids can be used in the control of $A$. aegypti. NAKAGAWA et al. (2017) assessed the concentration of cypermethrin and beta-cyfluthrin in dust under laboratory-controlled conditions and, after 112 days, cypermethrin and beta-cyfluthrin decreased only 12.7 and $16,4 \%$, respectively, suggesting that these active ingredients can remain for a long time in indoor places. Soon, the population might be exposed to different insecticides; therefore, further studies on the exposure of the population to the application of agrochemicals in urban areas are necessary.

Malathion significantly decreased in soil samples, with some degradation occurring in T240 and T360, even with the higher concentration retained in the soil at the time $(0.014 \mathrm{~g}$ i.a. $/ \mathrm{g}$ soil). Soil samples were contaminated with radiolabeled malathion because pesticide residues can be bound to the organic matter in soil with no possibility of extraction. In such cases, the only way to evaluate malathion persistence is by using radiolabeled material 
with a combustor for analysis. Nevertheless, using a combustor was not necessary, as the recovery of malathion in soil was $98 \%$ at Tzero, and the percentages of malathion remained high until T360. According to LEWIS et al. (2016), the half-life of malathion in the soil is 0.17 day under laboratory conditions, while in the field, it is 1 day. Consequently, malathion is not considered persistent. However, the results of this work indicate high persistence of the compound in soil. One factor that may have led to greater persistence is the use of malathion diluted in soybean oil. As malathion is applied by spraying, the solution is prepared in oil to avoid evaporation of small drops (BOUVIER et al., 2006), which leads to an increase in product stability. SAVOY et al. (2011) analyzed an oily malathion solution stored in a polyethylene bottle exposed to the external environment in São Paulo city for three months, during which malathion did not degrade.

The soil used in this study was not reactivated because some low-income houses in Brazil, like slums, had no coating on the ground, and our objective was to determine the indoor conditions of residences. Biodegradation in dry soil is quite difficult because the absence of water limits the microbial growth. After 240 and 360 days, even with a significant decrease in the concentration of malathion in the soil compared to the initial one, there was still about $0.014 \mathrm{~g}$ i.a./g soil (90\%) present at T240 and T360. This study did not assess the possible transfer of the product from contaminated soil to other surfaces or the toxicity of the concentration found in soil. Nonetheless, during summer, this product is used in greater quantities, and the concentration detected in the soil after 240 days may involve some risk to health.

During summer, children spend a great part of their time on the floor and in backyards wearing short clothes due to the high temperatures. The application of malathion increases during this time due to the intense rains, which cause a high proliferation of mosquitoes. In Brazil, this period also coincides with the summer break in schools, when children spend more time at their homes. Children who live in this environment may be at high risk of exposure, mainly by dermal contact and hand to mouth ingestion, due to their behavior. This is especially true for toddlers, as they are much closer to the floor, with a larger surface of their body exposed, compared to an adult. Moreover, they usually put their hands and other things into their mouths (WASON et al., 2013). An evaluation of the potential exposure from inhalation of atmospheric pesticides suggested that children, toddlers, and infants are exposed not only more often, but also for a longer period and to higher pesticide concentrations, which can lead to health risks (HUIZHEN et al., 2014).

The parameters collected in this study were based on laboratory studies. If Brazil starts using malathion diluted in oil again, the next important step is to conduct field experiments for the relevant range of conditions. Despite the need to control the $A$. aegypti to prevent dengue fever and other diseases, extensive studies on the potential health effects of using malathion diluted in oil in urban conditions are essential, mainly because in some Brazilian cities, insecticides are applied with doors and windows open and with the jet directed towards the interior of the residences for a maximum of five seconds (GOVERNO DO ESTADO DE SÃO PAULO, 2002).

\section{CONCLUSIONS}

Malathion diluted in oil is very stable and difficult to remove from surfaces. Malathion persistence was high in washed cotton cloths, a surface that can come into direct contact with the body. Malathion hardly degraded in dry soil.

\section{ACKNOWLEDGMENTS}

This project was funded by Fundação de Amparo à Pesquisa do Estado de São Paulo — FAPESP (Project 2012/51164-0).

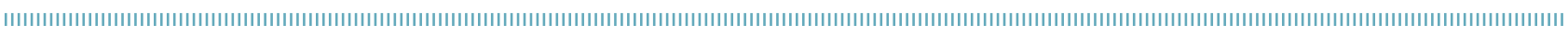

\section{REFERENCES}

ARAUJO, R.V.; ALBERTINI, M.R.; COSTA-DA-SILVA, A.L.; SUESDEK, L.; FRANCESCHI, N.C.; BASTOS, N.M.; KATZ, G.; CARDOSO, V.A.; CASTRO, B.C.; CAPURRO, M.L.; ALLEGRO, V.L. São Paulo urban heat islands have a higher incidence of dengue than other urban areas. The Brazilian Journal of Infectious Diseases, v.19, n.2, p.146-155, 2015 . https://doi.org/10.1016/j. bjid.2014.10.004

ASTIZ, M.; ARNAL, N.; ALANIZ, M.J.T.; MARRA, C.A. Occupational exposure characterization in professional sprayers: Clinical utility of oxidative stress biomarkers. Environmental Toxicology and Pharmacology, v.32, n.2, p.249-258, 2011 . https://doi. org/10.1016/j.etap.2011.05.010
BOUVIER, G.; BLANCHARD, O.; MOMAS, I.; SETA, N. Pesticide exposure of non-occupationally exposed subjects compared to some occupational exposure: A French pilot study. Science of The Total Environment, v.366, n. 1, p.74-91, 2006. https://doi. org/10.1016/j.scitotenv.2005.08.016.

CENTERS FOR DISEASE CONTROL AND PREVENTION (CDC). Dengue map. Available from: http://www.healthmap.org/dengue/ en/. Accessed on: Dec. 01 2015a.

CENTERS FOR DISEASE CONTROL AND PREVENTION (CDC). Dengue. Available from: http://www.cdc.gov/dengue/. Accessed on: Dec. $012015 b$. 
CETTIER, J.; BAYLE, M.L.; BÉRANGER, R.; BILLOIR, E.; NUCKOLS, J.R.; COMBOURIEU, B.; FERVERS, B. Efficiency of wipe sampling on hard surfaces for pesticides and $\mathrm{PCB}$ residues in dust. Science of The Total Environment, v.505, p.11-21, 2015. https://doi. org/10.1016/j.scitotenv.2014.09.086

COSTA, A.I.P.; NATAL, D. Distribuição espacial da dengue e determinantes socioeconômicos em localidade urbana no sudeste do Brasil. Revista de Saúde Pública, v.32, n.2, p.232-236, 1998. http://dx.doi.org/10.1590/S0034-89101998000300005

CRUZ MÁRQUEZ, M.; ARREBOLA, F.J.; EGEA GONZÁLEZ, F.J.; CASTRO, C.M.L.; MARTÍNEZ VIDAL, J.L. Gas chromatographictandem mass spectrometric analytical method for the study of inhalation, potential dermal and actual exposure of agricultural workers to the pesticide malathion. Journal of Chromatography A, v.939, n.1-2, p.79-89, 2001.

DAVIES, J.E.; FREED, V.H.; ENOS H.F., DUNCAN, R.C.; BARQUET, A.; MORGADE, C.; PETERS, L.J.; DANAUSKAS, J.X. Reduction of pesticide exposure with protective clothing for applicators and mixers. Journal of Occupational and Environmental Medicine, v.24, n.6, p.464-468, 1982.

ENVIRONMENTAL PROTECTION AGENCY UNITED STATES (EPA). Method 3510 C Separatory funnel liquid-liquid extraction. Available from: https://www.epa.gov/sites/production/files/2015-12/ documents/3510c.pdf. Accessed on: June 132019.

GENG, X.; SHAO, H.; ZHANG, Z.; NG, J.C.; PENG, C. Malathion-induced testicular toxicity is associated with spermatogenic apoptosis and alterations in testicular enzymes and hormone levels in male Wistar rats. Environmental Toxicology and Pharmacology, v.39, n.2, p.659-667, 2015. https://doi.org/10.1016/j.etap.2015.01.010

GOVERNO DO ESTADO DE SÃO PAULO. Normas e recomendações técnicas Para vigilância e controle do Aedes Aegypti no Estado de São Paulo. São Paulo: Secretaria de Estado da Saúde, Superintendência de Controle de Endemias, 2002. 70p. http://www.saude.sp.gov. $\mathrm{br} /$ sucen-superintendencia-de-controle-de-endemias/homepage / downloads/arquivos-arboviroses-todas. Accessed on: Jun. 302018.

HERMANN, L.L.; GUPTA, S.B.; MANOFF, S.B.; KALAYANAROOJ, S.; GIBBONS, R.V.; COLLER, B.A.G. Advances in the understanding, management, and prevention of dengue. Journal of Clinical Virology, v.64,p.153-159,2015. https://doi.org/10.1016/j.jcv.2014.08.031

HUIZHEN, L.; HONGZHU, M.; LYDY, M.J.; JING, Y. Occurrence, seasonal variation and inhalation exposure of atmospheric organophosphate and pyrethroid pesticides in an urban community in South China. Chemosphere, v.95, p.363-369, 2014. https:// doi.org/10.1016/j.chemosphere.2013.09.046

INTERNATIONAL AGENCY FOR RESEARCH ON CANCER (IARC). IARC Monographs Volume 112: evaluation of five organophosphate insecticides and herbicides. Available from: http://www.iarc. $\mathrm{fr} /$ en/media-centre/iarcnews/pdf/MonographVolume 1 12.pdf. Accessed on: Oct. 052015.

LEME, T.S.; PAPINI, S.; VIEIRA, E., LUCHINI, L.C. Avaliação da vestimenta utilizada como equipamento de proteção individual pelos aplicadores de malationa no controle da Dengue em São Paulo, Brasil. Cadernos de Saúde Pública, v.30, n.3, p.567-576, 2014. https://doi.org/10.1590/0102-311X00144912

LEWIS, K.A.; TZILIVAKIS, J.; WARNER, D.J.; GREEN, A. An international database for pesticide risk assessments and management. Human and Ecological Risk Assessment: An International Journal, v.22, n.4, p.1050-1064, 2016. https:// doi.org/10.1080/10807039.2015.1133242

NAKAGAWA, L.E.; COSTA, A.R.; POLATTO, R.; DO NASCIMENTO, C.M.; PAPINI, S. Pyrethroid concentrations and persistence following indoor application. Environmental Toxicology and Chemistry, v.36, n. 11 , p. 2895-2898, 2017. https://doi.org/10.1002/etc.3860

PAPINI, S.; VIEIRA, E.; LEME, T.S.; FERREIRA, R.C.B.; LUCHINI, L.C. Resíduos de malationa em vestimentas de equipamento de proteção individual, após lavagens usados em nebulizações do Aedes Aegypti. Revista Brasileira de Geografia Médica e da Saúde, v.12, n.22, p.134-138, 2016.

SAVOY, V.L.T.; PAPINI, S.; MONTENEGRO NETTO, H.; PRISCO, R.C.B. Avaliação da calda de aplicação de malationa em óleo vegetal utilizada no controle da dengue. Biológico, v.73, N.1, p.59-60, 2011.

SNOGRASS, H.L. Permethrin transfer from treated cloth to the skin surface: potential for exposure in humans. Journal of Toxicology and Environmental Health, v.35, n.2, p.91-105, 1992. https:// doi.org/10.1080/15287399209531598

TANG, W.; WANG, D.; WANG, J.; WU, Z.; LI, L.; HUANG, M.; XU, S.; YAN, D. Pyrethroid pesticide residues in the global environment: An overview. Chemosphere, v.191, p.990-1007, 2018. https:// doi.org/10.1016/j.chemosphere.2017.10.115

TANOBE, V.O.A.; SYDENSTRICKER, T.H.D.; MUNARO, M.; AMICO, S.C. A comprehensive characterization of chemically treated Brazilian sponge-gourds (Luffa cylindrica). Polymer Testing, v.24, n.4, p.474-482, 2005. https://doi.org/10.1016/j. polymertesting.2004.12.004

TOMASELLO, D.; SCHLAGENHAUF, P. Chikungunya and dengue autochthonous cases in Europe, 2007 and 2012. Travel Medicine and Infectious Disease, 2013 , v. 1 1, n.5, p.274-284. https://doi. org/10.1016/j.tmaid.2013.07.006

WASON, S.C.; JULIEN, R.; PERRY, M.J.; SMITH, T.J.; LEVY, J.I. Modeling exposures to organophosphates and pyrethroids for children living in an urban low-income environment. Environmental Research, v.124, p.13-22, 2013. https://doi.org/10.1016/j. envres.2012.08.009

WORLDHEALTHORGANIZATION(WHO). Dengue: quidelines for diagnosis, treatment, prevention, and control. Geneva: WHO, 2009. Available from: http://whqlibdoc.who.int/publications/2009/9789241547871_ eng.pdf. Accessed on: Dec. 012016.

ZOUBIRI, S. Chemical characteristics of aerosol insecticide deposition in indoor surfaces. Arabian Journal of Chemistry, v.4, n.2, p.153-158, 2011 . https://doi.org/10.1016/j. arabjc. 2010.06 .030

(c) 2019 Instituto Biológico

This is an open access article distributed under the terms of the Creative Commons license. 